\title{
Tributes
}

\section{Pa Fálétí, Another Icon Departs}

\author{
Femi Ọsộfisan \\ Distinguished Profesor of Performing Arts \\ Kwara State University \\ Malete \\ Nigeria \\ okinbalaunko@yahoo.com
}

\begin{abstract}
Where shall we seek him?
Where find him, call him?

A ń wa, a ò ríi...
\end{abstract}

Pa Fálétí is gone, never more to answer our calls or supplications, except from the other side, in the surrogate voice of an ancestor. But we do not mourn him. Rather, the mourning is for ourselves, for those of us left behind. What we mourn indeed is not his passing, but the void that stares us in the face, the apprehension we feel that there is no immediate successor to replace him. But still, we have to accept this not as a defeat but a collective challenge.

We do not indeed mourn the loss of Fálétí, because in Yorùbáland our custom is not to shed tears of grief for men or women who have lived a long and amply fecund life and left a bounteous legacy for their offspring. Why should one cry for a life that grew to sedate ripeness, mellowed in dignity, and is remembered everywhere with affection and respect? No. Instead, we celebrate such men joyously. We bring out the drums and sing our sonorous songs and adorn ourselves in our finest robes. We give ourselves generously to merriment and feasting and thanksgiving. We laud their achievements and serenade them as luminous inspiration to the living. Adébáyọ Fálétí has gone but not gone: his presence will surround us forever because of what he accomplished for our culture and our people.

While he was with us, we all recollect, Pa Fálétí was simply different. He was, and lived his life like, a magnificent cultural icon, a symbol of the best that our culture represented but has sadly lost, a veritable living archive of the 
Yorùbá-indeed, the entire black African's-weltanschaung. His appearance, when you met him, said it all. He wore his cap in a peculiar signature style, with an unusually long top tapering jauntily to the left of his head like a hunter's, and just as mysteriously suggestive of carrying secret herbs and powers. [Curious, I asked him one day why he wore his cap in this strange manner, and he replied, “Oh, forgive me, it's because I don't know how to put on a cap! Mi ò mọ filàá de ni! Má bínú!”]

If I remember him therefore, it is for all these qualities-his humility in spite of his deep knowledge and wisdom, his constant concern for decency and self-respect in all his conduct, his unassuming, easily approachable bearing in spite of his immense stature, and above all, his killing sense of humour, most often directed at himself in wry bemusement. To spend some time in his company was to gain an invaluable opportunity for self-enrichment. I can testify to all these from numerous episodes, but for this occasion I shall select only one that I believe to be fairly representative of the essence of his character.

This was some years back. We were returning, three of us, from a trip to Ado Èkìti, where we had gone to preview a film by that enormously gifted producer, Mrs Abiodun Ibitola, now late, of Remdel Optimum Communications. The third person, you don't have to guess, was Professor Akínwùmí İsọ̣lá, the one we call 'Honest Man', author of the original work from which the film script had been adapted. You can imagine therefore, with these two heavyweight fabulists and dramatists aboard in the car, the kind of trip it turned out to be.

The fact was that I learnt a lot and laughed a lot. It was a pleasure to listen to these two artists, and find out, in those intimate moments, how deeply knowledgeable both of them were in the lore and customs of our land, and how sensitive they were to our rapidly changing times and to the corroding force of western modernity.

Almost every tree in the forest as we went on, almost every bird that flew past, would immediately draw out some anecdote, especially from Pa Fálétí. He would announce the name of the tree or animal and go on to narrate some story or legend about it, as well as its significance to Yorùbá oral traditions. This would then be invariably followed by some pertinent song or oriki whose often cryptic meaning he would also decipher for me. It was an incredible performance which, to this day, I regret not having recorded. Where again will I ever learn these things?

And then came an unexpected spectacle. We had stopped, as most people usually do, at one of the make-shift market stalls which the peasants erect along the road for travellers, to buy some yams and fruit. Then, as we started to haggle over the prices, we saw other cars begin to stop one after another, 
their doors swinging open, and their occupants hurrying out towards us. Or rather, towards Pa Fálétí, whom they had recognized as they drove past. Gleefully, effusively, beaming with pride and delight, they poured out their homage to him, displaying emotions that ranged from astonishment to sheer wonder to unbelievable rapture. Some of them even offered to pay for the yams he wanted!

Just imagine the scene, as I stood by and marvelled. I was supposed to be famous as a writer, recognized in the press and in learned circles as the most important of the post-Șóyínká generation, my books studied in schools here and abroad-but not one among the enthusiastic crowd milling around Fálétí even conceded as much as a glance at me!

And yet, by contrast, Fálétí was a simple and unassuming man as far as public life was concerned. He was not a government minister or politician or businessman, although he had once headed a public broadcasting corporation. A warm personality by nature, he was yet not given to showy appearances in the media and was very rarely invited to official parties or seen among the noisy crowd of our flamboyant affluent.

But there we were, somewhere deep in the Èkìti forest, and he was being accorded attention and admiration more reverent than that enjoyed by any media idol, with admirers freely and spontaneously falling on one another in the scramble to gain his notice and pay for his purchases!

How could one miss the import of that scene? The lesson was clear, that what matters in life in the end is not material wealth or social status, but rather, the immeasurable integrity of a dignified life. In place of the fripperies that most of our people worship, Fálétí distinguished himself by his simplicity, and a deep erudition. He showed a genuine commitment to the cause of the people, and to the survival of those essential values we associate with omolúàbí. And here was his reward, as the people, both poor and wealthy, educated and illiterate, lavished him with praises for being their faithful and unrelenting spokesman all through his career. Yes, the honour that the government failed to give him had become irrelevant-Pa Fálétí had erected his own immortal plinth of esteem where history matters, deep in the heart of the people.

The other remarkable thing about that trip which I began to mention above, was his delicious sense of humour. Laughter filled the car every moment. Just like his companion, Honest Man, Fálétí laughed easily, and frequently, and told the most outrageous jokes to crack your ribs. There is no space here unfortunately to recount them. But they showed that he was a man without bitterness, with no room in his capacious heart for rancour or resentment, so much so indeed that I am willing to wager that, wherever he may be 
now, looking at us, he will be laughing at us, just as he laughed at life itself when he was here with us.

I must stop here. With the departure of Papa Fálétí, the nation has lost a magnificent treasure-trove, a library of traditional lore and ancestral wisdom, an elder who never grew tedious or stale, an exemplar of all that is decent, proper, and worth preserving. It is a loss that will be hard to replace; a life impossible to replicate; a story we must keep in our memory, to cherish and learn from.

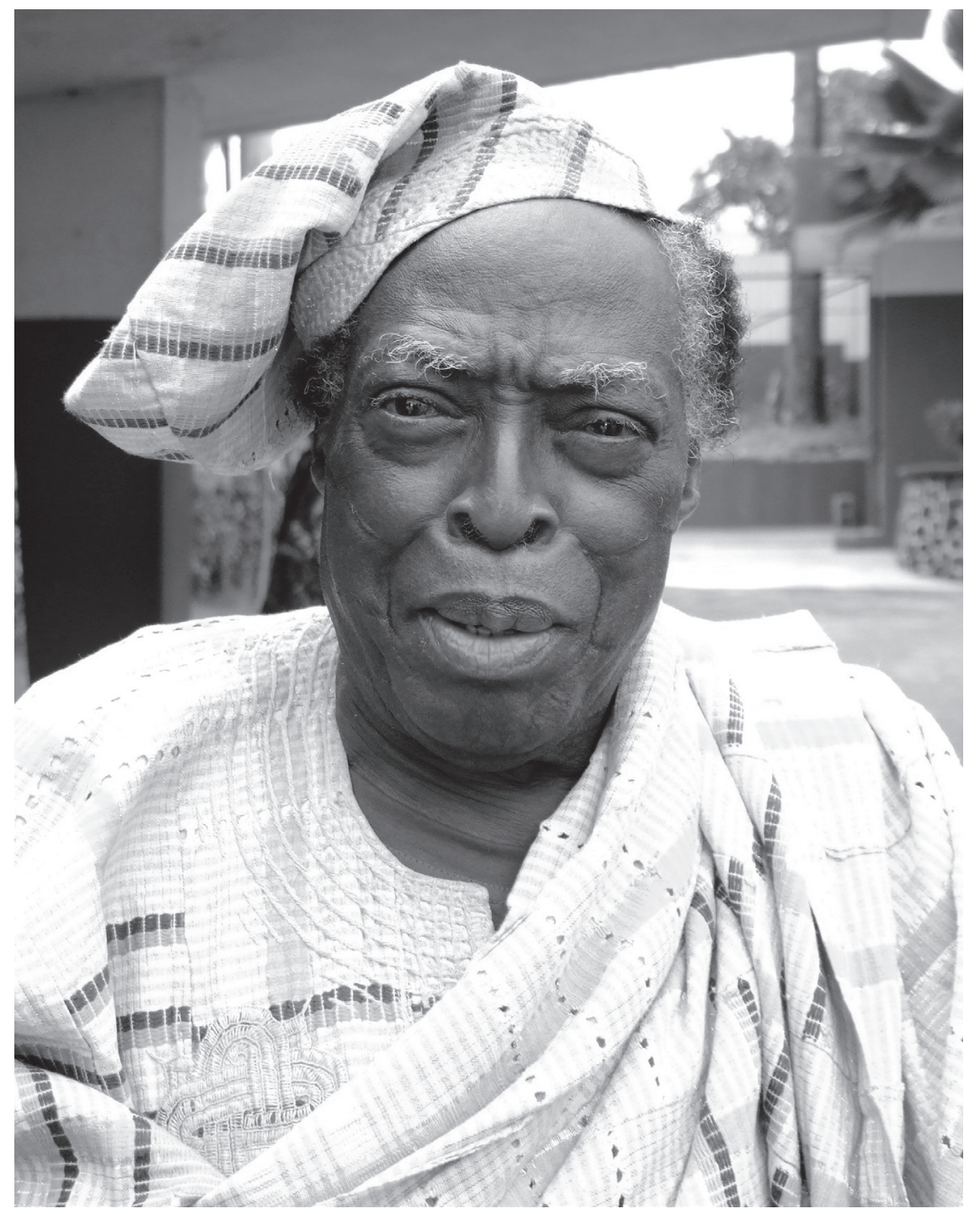

